\title{
Hand Digit Skin
}

National Cancer Institute

\section{Source}

National Cancer Institute. Hand Digit Skin. NCI Thesaurus. Code C52720.

The skin covering the fingers or appendages of the hand. 